\title{
Social Media and Marketing: Viral Marketing
}

\author{
Asst. Prof. Dr. Şeyda Akyol \\ Lecturer in Marmara University, Faculty of Communication, \\ Department of Public Relations and Publicity, Field of Interpersonal Communication
}

\section{Doi:10.5901/ajis.2013.v2n8p586}

\begin{abstract}
Due to increasing competition during the late years organizations find themselves in need of creating new marketing technics. Companies try to find out how to keep competing in the Internet age. Now communication skills more important than marketing itself. Therefore most of the leading companies realized that marketing and marketing methods have to changed and they started to use interactive technics while they releasing new products or service to the market.In the globalized world, the change in the life styles, social, economical and political conversions, technological developments lead the marketers to use viral marketing effectively in the search of new medium. The way people used to communicate has completely been changed and it became easier for consumers to share their experiences about products, brands and services through internet.Nowadays, conducting more efficient marketing activities by organizations is direct proportionate to their compliance with technology and marketing approaches. Especially, the emergence of internet and consumers' desire to have a word have directed marketing experts to digital environment as an alternative platform. In this study, the viral marketing technics, supported by different examples, are emphasized.
\end{abstract}

Keywords: social media, marketing on internet, viral marketing, e-word-of-mouth

\section{Introduction}

Technological developments have changed people's life styles. Many differences and features have started to come out in line with the diversification in the field of media. Therefore, marketing communication, which composes of activities that lead customers to buy new products, has gained importance.

As Internet has become widespread, word of mouth marketing has created several new concepts of marketing communication. One of the new advantages brought to marketers by this technological innovation or opportunities is viral marketing practice. Viral marketing is a type of word of mouth communication on Internet, which is the newest platform.

As social networking sites have a significant impact on consumers' decision-making process and behaviors, these sites cannot be disregarded by brands of which the target audience actively uses digital channels. This study focuses on the meaning of social networks for marketing communication and how these networks are used.

\section{Social Media Concept}

Today Internet usage is growing day by day and individuals' dialogues together with their posts on Internet constitute social media. Social media offers many opportunities to Internet users.

Social Media "is a term used for online tools and web sites that offer a chance for mutual interaction through information, opinions, interests and sharing". As also stated in its definition, social media mediates in creating communities and networks by encouraging participation and being interested (Sayımer: 2008: 123). In Web2.0 development where a participation culture started to attract attentions, users should play the role of a creator or participant (Tosun, Levi, :2010:95). Thus, it created not only a new consumer (user) but also platforms where they manage information and contents. Everyone can create, share, exchange, direct, send, affect, examine and use limitless contents on created collective media (Alikılıç, 2011:14).

It would not be wrong to say that social media enables companies to communicate with their customers and also customers to exchange ideas directly with each other. The timing and frequency of consumers' communication on social media are managed by consumers, not managers. This contrasts with traditional marketing concept. For this reason, social media can be considered as an important change in terms of marketing (Tosun, Levi, 2010:94). As social media has become practical and cost effective, many brands started to use social networks. 


\section{Viral Marketing}

Viral marketing is a type of word of mouth marketing technique used on Internet (Quoted from Snyder, 2004 by: Dahan, 2012). Viral marketing concept, which was first used by Steve Jurvetson and Tim Draper (Pelphs vd.), is defined as "a word of mouth marketing technique used in relation to a brand, product or service similar to the spread of viruses on social networks on electronic media" (Quoted from MindComet, 20062 by: Dahan,2012). It is a part of electronic word of mouth marketing because it is a part of electronic media and the main reason of its separation is that the starting point of this activity is known or thought to be companies. Dialogues related to services or products started with individuals' own will are observed in viral marketing activities. In this activity, companies create interesting contents about which individuals can talk and share between each other and this content spreads like a virus (Quoted from Wilson, 2005 by: Dahan, 2012). In line with this information, viral marketing can be defined as various online word of mouth marketing practices that use brand, product or service related contents created by companies in a way that encourages interpersonal communication in a wide range of applications (Quoted from Eckler and Rodgers 2010, Golan and Zaidner 2008 by: Dahan 2012).

Word of mouth marketing is regarded as the oldest known marketing communication medium. It is considered to be the most reliable type of advertisement, as the source communicating the message from mouth to mouth is a known and reliable character. For this reason, word of mouth marketing has attracted the attention of many researchers. The importance of sincere conversations between consumers in increasing sales was first noticed in 1960s (Kalpaklioğlu, Toros, 2011). According to the definition given by Word of Mouth Marketing Association / WOMMA, word of mouth marketing is "the transfer of marketing related information created by consumers to other consumers". Moreover, word of mouth marketing "also covers the efforts of the organizations to lead consumers to create marketing related contents and communicate these contents to other consumers" (Quoted from http://www.womma.org/content/womma_term _framework.pdf by: Kalpaklioğlu, Toros, 2011).

Viral marketing spreads thanks to people's natural motive to communicate and inform other people in their networks about the things they find interesting or useful. Viral marketing is a tactic that aims to communicate the planned contents to a specific target audience in the most effective and sincere manner by using communication channels. Interactive applications and especially videos, advergames, pictures, audio files, presentations and even text contents are the most important tools of viral marketing. These products become marketing tools with the addition of commercial messages. A viral ad can be categorized into two: The first one is a video film, which is created by a user and creates a positive impact incidentally on a brand and shared by this user with other users on social media. The second one is a company having a professional team to make and spread a viral advertisement. However, what is important here and what is different from traditional commercial films is that the viral ad is created in a way that seems to be created by an amateur user (Quoted from Eckler, Bolls, 2011 by: Uraltaş, Bahadırlı, 2012). These video films interest and are shared by users. Thus, brand name starts to be known by other users.

People talk to each other in daily life to share their opinions and comments about a product (Kalpaklioğlu, Toros, 2011). The effect of people on other people is nine times more powerful than the effect of an ad on a magazine, newspaper or TV channel (Quoted from Katz \& Lazarsfeld, 1955:9 by: Kalpaklioğlu, Toros, 2011).

The difference between viral marketing and other activities is that it has an authentic content that provokes individuals. Individuals share this creative content due to its authenticity on electronic social networks and thus, this content reaches millions of people by being communicated from one individual to another on social networks (Quoted from Wilson 2005 by: Dahan 2012). This content, which spreads like a virus very fastly from one individual to another, increases awareness even if it does not affect the sales of the related brand, product or service instantly (Quoted from Davis and Khanazchi 2008 by: Dahan 2012)

As the success of this marketing communication activity depends on the communication of the content by individuals, it is extremely important to understand the motives of individuals to share contents on electronic media (Quoted from Eckler and Rodgers 2010 by: Dahan 2012). Succeeding to motivate individuals to share this content can only be possible if the preconditions to target the right group of people and offer a creative content are fulfilled just like all the other marketing communication activities (Quoted from Phelps vd. 2004 by: Dahan 2012).

Internet is considered as the "fifth channel" following TV, radio, newspapers and magazines (Quoted from Cutler, 1990, s. 25 by: Alexander, 2006). It continues to grow as a useful communication channel that enables individuals and companies to share information fastly (Quoted from Townsend, 2001 by: Alexander, 2006) on an interactive and one-toone media (Quoted from Anderson, 2000 by: Alexander, 2006) (Alexander, 2006). Internet has revolutionized communication technology by enabling consumers to interact with each other fastly and easily. The efficiency and 
distribution of WOM has been increased and accordingly, a new concept known as electronic WOM has come out (eWOM) (Quoted from Brown, Broderick and Lee 2007; Dellarocas, 2003; Dwyer, 2007; Goldenerg, Libai, and Muller, 2001; Goldsmith and Horowitz 2006 by: Kim 2012). Hennig-Thurau vd. (Quoted from 2004 by: Kim 2012). eWOM is defined as follows: "All kinds of positive and negative expression that belongs to potential, real or former customers in relation to a product or company and that is announced to limitless individuals and companies through Internet" (s. 39) according to Klein (Quoted from 1998 by: Kim 2012). WOM process also enables customers to understand abstract products while searching for WOM information from an experienced source. For this reason, online customer comments on restaurants, travel destinations and hotels have become very remarkable information sources for consumers (Quoted from Pan vd., 2007 by: Kim 2012). This communication is made by using different channels: For example, emails, discussion forums, main pages, blogs, restaurant comment sites (urbanspoon.com) and social networking sites (such as Facebook and MySpace) (Quoted from Goldsmith vd., 2006; Vilpponen, Winter and Sundqvist,2006 by: Kim 2012). Thanks to this anonymous interaction, consumers can exchange opinions about products or services affected by the information on Internet (Quoted from Goldsmith vd., 2006; Schlosser, 2005 by: Kim 2012). For example, Vermeulen and Seegers (2009) conducted an experimental study with the purpose of measuring the effect of online comments on travel decisions. According to their conclusion, receiving online comments increases awareness about hotels and positive comments lead to positive attitudes towards hotels. Additionally, customers can compare prices and the quality of products and services. They also have the chance to communicate with other marketers and consumers on online platforms (Quoted from Goldsmith vd., 2006 by: Kim 2012)). According to Goldsmith vd. (2006), marketers know the power of eWOM to earn the loyal customers. Now many companies endeavor and make significant investments in order to increase the number of positive eWOM news (Quoted from Goldenberg, Libai and Muller, 2001 by: Kim 2012).

Being an informal communication method that reflects the evaluation of the individuals on products and services, WOM (Word of Mouth Marketing) has long been known to have powerful effects (Quoted from Brooks 1957; Dichter 1966 by: Taylor 2010). WOM can create a more powerful effect on customer attitudes, as it is believed to be more reliable and objective than commercial ads when compared to traditional ads (Quoted from Day 1971 by: Taylor, 2010) and as a result of this effect, the tendency of consumers to purchase (Quoted from Chevalier and Mayzlin 2006; Liu 2006 by: Taylor 2010) or adopt new technologies may increase (Quoted from Czepiel 1974 by: Taylor 2010). It is unquestionable that it is also more effective than the other persuasive techniques; WOM is four times more effective than personal sales and seven times more effective than advertisements according to a research made in the past (Quoted from Katz and Lazarsfeld 1955 by: Taylor 2010). Thanks to the digital communication revolution that occurred in the last decade, WOM has become more powerful than before. Usage of new informative communication channels -email, mobile phones, PDA (personal digital assistants), text messages, instant messages, blogs and Web sites - caused an amazing increase in sharing customer information (Quoted from Allsop vd.2007 by Taylor 2010). Today, customer can communicate with so many people very fastly and access distant locations in a very short period of time. For example, Susan Boyle, who is a 47-year old ordinary Scottish woman, joined the TV show "Britain's Got Talent" in 2009 and fascinated the audience by signing "I dreamed a dream". It was just two days after the show when her video was watched by more than 12 million times on an online platform. This was mostly thanks to WOM. This woman, who does not look like a pop star, succeeded to reach people at their homes not only in Britain but also in Europe and USA (Quoted from Usborn 2009 by: Taylor 2010).

Informative communication networks brought by modern communication technologies have surely changed the image of WOM. In today's "networked" world, not only a few competent people but also people from all levels with different effects and connections share word of mouth communication (Quoted from Smith vd. 2007 by: Taylor, 2010). Electronic WOM (eWOM) covers customer comments in emails, text messages, online videos, Web sites; computeraided channels such as social networking site like Facebook, MySpace and Linkedln and other electronic communication channels. Even though each tool has its own features, their common feature is the capability to distribute information very fastly to a very wide range of customers in different locations. Like the Susan Boyle example we just mentioned, if WOM reaches a critical level - defined by Gladwell (Quoted from 2000 by: Taylor, 2010) as "tipping point" - and spreads to wide communities, then it becomes "viral". Although this "process of becoming viral" is not fully understood by marketers, it is found to be very effective (Taylor, 2010).

According to a research conducted by White House Department of Consumer Relations, $90 \%$ of unsatisfied consumers state that they will not buy the product of the same brand anymore. Each unsatisfied consumer shares his/her negative experience with at least 9 people and 13\% of these consumers share it with more than 20 people. On the other hand, satisfied customers share their satisfaction with 5 people (Quoted from Misner, 1994:27 by: (Kalpaklioğlu, Toros, 2011). 74\% of people who hear those negative opinions prefer another brand (Quoted from Millward Brown, 2005:4 by: 
Kalpaklioğlu, Toros, 2011) and 74\% of the purchasing decision criteria depend on advices. Considering that one person communicated with approximately 25 different people every day, it is obvious that positive or negative opinions can spread very fastly (Quoted from Wilson, 1994:25 by: Kalpaklioğlu, Toros, 2011). This is the proof of viral marketing power.

The term of viral marketing was first used by Harvard Business School lecturer Jeffrey Rayport. He wrote an article named "The Virus Marketing" in 1996. Viral marketing concept was defined as "network-oriented word of mouth marketing" by Juvertson and Draper in 1997 and launched to announce Hotmail's free of charge email service (Quoted from Juvertson, www.dfj.com/cgi-bin/artman/publish/printer_steve_tim_may97.html by: Kalpaklioğlu, Toros, 2011). The number of users went up from 500,000 to 12 million in just one year after the "get your free email" message was placed below each email sent by Hotmail (Quoted from Godin, 2001:66 by: Kalpaklioğlu, Toros, 2011). Today, many international brands such as Tupperware, Microsoft and PepsiCo use viral marketing as their man marketing strategy. Recently, Burger King launched an online promotional campaign on its interactive web site which can be accessed at www.subservientchicken.com where consumers can visit and give commands to a man in a chicken suit. Moreover, site visitors can also inform their friends about this funny site by clicking the "tell my friend" link and providing the email address (Quoted from Eaton, J., www.docs.com/docs/42444246/e-word-of-mouthmarketing by: Kalpaklioğlu, Toros, 2011).

What is important here is that it is more likely to be adopted if it is very innovative and interesting. On the $1^{\text {st }}$ of April, Workopolis MSN.ca provided its Web site visitors the chance to send fake press releases to their friends. There were several templates including CEO, TV newsreader or supermodel that can be selected by the sender. The viral campaign gained more than expected success (Quoted from Sweeney, MacLellan \& Dorey, 2006:67 by: Kalpaklioğlu, Toros, 2011).

\section{Viral Marketing Techniques on Online Social Networks}

As a result of being a basic need for people, social networking sites were created to make the social network perceived, edited and announced to everybody. Thus, they were adopted by millions of people in a very short period of time (Quoted from Boyd, Ellison, 2007 by: Varnalı, 2012). Most of these sites enabled the existing social relations and/or social networks to be transferred to Internet. People socializing as crowded communities on digital platforms and this socialization becoming a norm have lead to many significant developments. As the most penetrable networks are generally the networks created by people in the same socio-economic group with similar interests, the contents transferred through digital social networks is spread in a targeted manner because the desire to fastly access information is one of the main reason of people frequently visiting digital social sites (Varnalı, 2012).

Creating social networks on online platforms has become very popular between various disciplines. Online networking sites such as Facebook, Twitter and Linkedln continue to add more than 100,000 users in a day. The fastest growing group on Facebook, which has more than 500 million active users, is the group of people aging 35+. Globally, more than 11.7 million hours per month are spent on Facebook and more than 200 million users access Facebook by using their mobile devices. Social media has also become popular among big hospitals and pharmaceutical companies. There are nearly 1,100 hospitals nationwide on Facebook, Twitter, YouTube, Linkedln or blogs. Various information ranging from recent developments in health sector to ongoing organization events are transferred among hospitals through these sites. Pharmaceutical companies have developed many social networking sites including disease support pages and special product information (Kukreja, Sheehan and Riggins, 2011).

Fortis Turkey has realized its first brand application on Facebook, which is a social networking site. 4.500 users in the first three days and 20.000 users in the first month joined "Fortis Turkey Cup Guessing Game". The application was started before group matching and users were allowed to guess game scores according to the league table. Those making the best score guess were listed at the end of each game week (Quoted from http://www.pctime.com.tr /habergoster.asp?id=599 by: Kalpaklioğlu, Toros, 2011).

British Airways, created a link between New York and London by using Twitter and designing Metrowin web page. The web page contains recommendations about where to go, what to eat and where to stay. Twitter is becoming more popular in Turkey day by day. Turkish Airlines and Pegasus Airlines send information about new destinations and sales promotions via Twitter (Quoted from Odabaşı, 2009 by: Kalpaklioğlu, Toros, 2011 24:6).

As seen, now brands and companies gather with consumers directly on social media. Social networking sites like Facebook, Twitter and MySpace have started to change companies' product marketing methods and ways of communication with consumers. It is important to know how to effectively use these social sites that offer new 
opportunities in terms of marketing.

\section{Conclusion}

Marketing concept is based on people's needs and today this concept has developed in line with the diversification of needs. As technological developments cause changes in people's needs, product variety is offered to fulfill these needs and tactics have been developed to sell products. This approach has given marketing concept a new dimension.

Today, it is getting hard to reach consumers by using traditional methods. As consumers are more informed about the things they purchase and consume, the job of marketers is getting harder. Characteristics, preferences and favorites of consumers are fastly changing. The methods of accessing information in globalizing world have also changed. Today, viral marketing that is based on "recommendation" has become a new trend for companies to enable their target audience/consumers to read, watch, see the given messages and adopt the brand. When it was realized that "recommendations" are effective for marketing, it started to be used as a marketing method.

Playing a significant role in marketing communication, the power of persuasion becomes more powerful with viral marketing, as the recommendation is received from a third party. Companies understanding the power and effectiveness of viral marketing use this communication technique while conducting their advertising, public relations and personal sales activities.

It is believed that viral marketing practices will become more powerful and develop more in the future. However, it is also stated that this process should carefully be used and monitored even though viral marketing messages are effective.

\section{References}

Alexander, Peter, Electronic Word-of-Mouth Communication: Factors that Influence the Forwarding of E-Mail Messages, ProQuest Information and Learning Company 300 North Zeeb Road, P.O. Box 1346 Ann Arbor, MI 48106-1346, April 2006.

Alikılıç,Özlem Aşman, Halkla Illişkiler 2.0:Sosyal Medyada Yeni Paydaşlar, Yeni Teknikler,Efil Yayınevi, İstanbul.

Carmen Cameraro, San Jose Rebeca, "Social and Attitudinal Determinants of Viral Marketing Dynamics", Computers in Human Behavior;Nov 2011, Vol.27lssue6, p2292-2300,9p.

Dahan, Sanje Gresi, "Sanal Dünyada E-Ağızdan Ağıza Pazarlama Üzerine Bir İnceleme", Sosyal Medya ve Ekonomi, Editörler: Tolga Kara,Ebru Özgen, Basım Yayım Dağııım A.Ş., İstanbul,2012.

Jarvis, Jeff, , Google Olsa Ne Yapardı?çev.Gökçe İnan, MediaCat Kitapları,Istanbul.

Jianmei, Yang,Canzhong,Yao,Weicheng,Ma,Guanrong,Chen,"A Study of the Spreading Scheme for Viral Marketing Based on a Complex Network Model",Physica A;Feb2010,Vol.389Isuue4,p859-870.

Kalpaklioğlu, Nur Undey , Toros, Nihal, "Viral Marketing Tecniques Within Online Social Network” Journal of Yasar University 2011 24(6) 4112-4129

Kim, DongHee, "The Hidden Drivers of Electronic Word-of-Mouth: The Case of Upscale Cafe" A Thesis, Submitted to the Facultyof Purdue University In Partial Fulfillment of the Requirements for the Degree of Master of Science Purdue University West Lafayette, August 2012.

Kukreja, Pavnit, Sheehan, Amy Heck,Riggins, Jennifer, Research Articles, "Use of Social Media by Pharmacy Preceptors", American Journal of Pharmaceutical Education 2011; 75 (9) Article 176.

Sayımer, İdil, Sanal Ortamda Halkla Iliş̧kiler, Beta Basım A.Ş.,2008.İstanbul

Tasner, Michael, Anında Pazarlama: Web 3.0 Pazarlama Kılavuzu, çev.Aytül Özer, MediaCat Kitapları, İstanbul.

Taylor, David George, "I Speak, Therefore I am:" Identitiy and Self-Construction as Motivation to Engage in Electronic Word of Mouth, University of North Texas, August, 2010.

Tosun, Babür Nurhan, Levi, Eser, "Marka Topluluğu Yaklaşımında Sosyal Medyanın Kullanımı", Derleyen: Aydoğan, Filiz, Akyüz,Ayşen, İkinci Medya çağında İnternet, Alfa Basım Yayım Dağııım San.ve Tic.ltt.Şti., İstanbul,2010.

Uraltaş, Nazıım Tüzel, Bahadırlı, L.Serah, "Elektronik Perakendecilik ve Bir Reklam Mecrası Olarak Sosyal Ağ Siteleri", Editörler:Tolga Kara, Ebru Özgen, Sosyal Medya:Akademi, Beta Basım Yayım Dağııım A.Ş., İstanbul,2012.

Varnall, Kaan, Dijital Tutulma: Pazarlama Iletişimi ve İnsan, Kapital Medya Hizmetleri A.Ş., İstanbul,2012. 